\title{
A comparison study of range-extended engines for electric vehicle based on vehicle simulator
}

\author{
Bambang Wahono $^{1^{*}}$, Arifin Nur ${ }^{1}$, Widodo Budi Santoso ${ }^{1}$ and Achmad Praptijanto ${ }^{1}$ \\ ${ }^{1}$ Research Centre for Electrical Power \& Mechatronics, Indonesian Institute of Sciences \\ Komp LIPI JlCisitu 21/54D, Gd 20, Bandung 40135, Indonesia \\ "Email: bambangwahono80@yahoo.co.id, bamb053@lipi.go.id \\ Phone: +62222503055; Fax: +62222504773
}

\begin{abstract}
Electric vehicles have several disadvantages compared to conventional vehicles, such as their road ability and vehicle weight. To overcome these problems, range-extended engine technology has been developed. A range extender is a generator set that consists of an internal combustion engine coupled with a generator that operates when it is required. A vehicle simulator was deployed to compare the performance of three types of range-extended engines i.e. 1-cylinder $389 \mathrm{cc}, 1$-cylinder $494 \mathrm{cc}$ and 2-cylinder 988 cc gasoline engines. The best type chosen was afterwards to be coupled with an electric vehicle. The performance data of each internal combustion engine was collected using experiment and simulation data. Two types of driving cycle, the Federal Test Procedure cycle and Artemis Rural Road cycle, were chosen to compare the optimum road ability of the vehicle. The result shows that the 2-cylinder $988 \mathrm{cc}$ range-extended engine has the best performance, with an electrical motor energy consumption decrease of up to $83.26 \%$, fuel consumption increase for the range-extended engine of up to $3.91 \mathrm{~L} / \mathrm{km}$, and a road ability increase of up to $232.79 \%$ compared to a pure electric vehicle.
\end{abstract}

Keywords: Range extender; AVL Cruise; fuel consumption; electric vehicle; simulation.

\section{INTRODUCTION}

One of the biggest environmental problems in the the world is air pollution. According to research conducted by the World Health Organization inn 2012, air pollution kills 7 million people per year globally [1]. One of the big causes of air pollution in the world is the significant increase of conventional vehicle numbers in recent years $[2,3]$. In Indonesia, air pollution from the transportation sector, especially in major cities, has reached a critical point that is very dangerous [4]. Looking at these conditions, a new alternative fuel or a new vehicle technology to help reduce air pollution and save fuel consumption is required. Many researchers have used alternative fuels such as bioethanol, alcohol or hydrogen [5-13], but these alternative fuels still have some problems such as unsustainability and difficulties with their storage systems $[14,15]$. Electric vehicles (EV) [16, 17] and hybrid electric vehicles (HEV) [18, 19]have the most potential as new technologies to address these issues [20-24]. People at the moment are giving great attention to EV and HEV due to the rising shortage of global oil supply and skyrocketing oil prices [25]. Compared to conventional vehicles, electric vehicles have advantages such as zero emissions and good acceleration performance. On the other hand, electric vehicles have two disadvantages, i.e. in terms of the vehicle weight and limited distance (road ability). A range extender is a solution to solve the 
problem of electric vehicles and is a small electricity generator (generator-set) which operates when needed and under its optimum zone. The main component of the range extender is the generator and internal or external combustion engine, where the internal or external combustion engine is coupled to the generator in series configuration. The main function of the range extender for an electric vehicle is to extend the vehicle's mileage.

Operation of the range extender is initiated if the battery SOC (state of charge) of the electric vehicle drops below a specified level. In this condition, the engine provides the electricity by recharging the battery or directly driving the electric vehicle during travel and continues the vehicle operation [26]. The difference with a plug-in hybrid electric vehicle is that the electric motor always propels the wheels, with the engine acting as a generator to recharge the battery of the vehicle when it becomes depleted or to directly propel the vehicle. So, range-extended electric vehicles could significantly reduce emissions and fuel consumption [27]. Today, the development of vehicle simulators is increasing rapidly. The vehicle simulator is a powerful tool that can estimate the performance of all models of vehicle including hybrid electric vehicles without requiring their physical construction. This simulator allows the user to make a configuration of vehicle components in an inexpensive and quick model. Some famous vehicle simulators developed to study advanced vehicle models include ADVISOR [28], MATLAB/SIMULINK [29], AVL CRUISE [30], and PSAT [31]. Compared to other vehicle simulators, AVL CRUISE has many advantages; it is less complex to build the vehicle model, the time to calculate the model is short, the result of calculation is accurate and it is easy to change the model [32]. In this research, AVL CRUISE is used to build the model of a range-extended electric vehicle.

The purpose of this paper is to compare the performance of some internal combustion engines as one of the main components of the range extender to improve the performance of electric vehicles. The best internal combustion engine model can then be used as one of the range extender components and installed in an Indonesian Institute of Science (LIPI) electric vehicle in particular, and more generally in other electric vehicles. To realize this purpose, data collected from the Internal Combustion Engine Laboratory, Research Centre for Electrical Power \& Mechatronics, Indonesian Institute of Sciences, and data from simulation by AVL BOOST is used to build the model of a range-extended electric vehicle in AVL CRUISE powertrain simulation software [33].

\section{CONFIGURATION OF RANGE-EXTENDED ELECTRIC VEHICLE}

There are three main configurations of hybrid electric vehicle: parallel configuration, series configuration and a combined parallel-series configuration. Some vehicles have a system that combines parallel and series configuration in such a way that the internal combustion engine can change the position in the schedule to work with a favorable system. The parallel configuration of hybrid electric vehicle, shown in Figure 1, has the main features of internal combustion engines, an electric motor and planetary gear as the power split. The internal combustion engine directly coupled to the transmission has a direct mechanical transmission, with the wheels as the electric motor. This configuration has the advantage of being able to give more power to the vehicle due to the fact that the ICE (internal combustion engine) and electric motor can work together. The series configuration of hybrid electric vehicle also has an ICE and electric motor, but only the electric motor is connected directly to the drive train, so the vehicle is driven by electric traction. It has its engine connected to the generator, which functions 
to recharge the batteries when the vehicle is being driven. Compared to the parallel configuration, the series configuration of hybrid electric vehicle has advantages such as being simpler than the parallel configuration, the ICE can be located anywhere because a mechanical transmission with the wheel is not necessary, and the engine works efficiently because it works in a constant rpm condition.

The range-extended electric vehicle system is shown in Figure 2. A series configuration is used as the main system in this hybrid electric vehicle model. The system is connected with several sub-systems such as the internal combustion engine, generator, battery, electronic management system and electric motor. The electric motor converts electric energy from the battery to the mechanical works and propels the tyre, while the internal combustion engine is coupled to the generator to generate electric energy to recharge the battery. Finally, the electronic management system is used to control all of the systems to work in an optimum region. The range-extended electric vehicle has two operation modes: pure electric vehicle and range-extended electric vehicle. If the distance is short, the vehicle operates in pure electric vehicle mode without the range extender. If the distance is long, the vehicle operates in rangeextended electric vehicle mode. The range extender will be off as long as there is sufficient energy in the battery for pure electric driving (charge depletion mode, CD) and will be activated whenever the state of charge (SOC) drops below a certain level (charge sustaining mode, CS). The range extender will work until the desired SOC is achieved.

In this research, three types of ICE were used to simulate the range-extended electric vehicle model to determine which one gave the best performance, whether the 1 -cylinder $389 \mathrm{cc}$, 1-cylinder $494 \mathrm{cc}$ or 2 -cylinder $988 \mathrm{cc}$. The generator model was based on AF 130 type synchronous-axial flux with nominal output power of $64 \mathrm{~kW}$, maximum speed $8000 \mathrm{rpm}$ and weight $30.5 \mathrm{~kg}$ [34]. The energy storage of the electric vehicle was obtained with 30 lithium-ion $\left(\mathrm{LiFeYPO}_{4}\right)$ battery cells in series configuration with a weight of $7.3 \mathrm{~kg}$, capacity $200 \mathrm{Ah}$, nominal voltage $3.2 \mathrm{~V}$ and size $362 \times 256 \times 56 \mathrm{~mm}^{3}$ [35]. The electric motor model was based on the HPEVS AC-20 96V, AC induction motor with a Curtis $650 \mathrm{amp}$ regen motor controller [36]. The main basic parameters of the range-extended electric vehicle are given in Table 1.

Table 1. Main basic parameters of range-extended electric vehicle (REEV)

\begin{tabular}{lc}
\hline \multicolumn{1}{c}{ Parameter } & Range-extended electric vehicle \\
\hline Curb weight & $1200 \mathrm{~kg}$ \\
Gross weight & $1580 \mathrm{~kg}$ \\
Frontal area & $1.97 \mathrm{~m}^{2}$ \\
Dynamic rolling radius & $301 \mathrm{~mm}$ \\
Final drive transmission ratio & 4.266 \\
Battery model & WB-LYP200AHA \\
Generator model & Generator AF-130 \\
Electric motor model & HPEVS AC-20 96V 650 Amps \\
Engine & 1-cylinder 389cc, 1-cylinder 494cc, \\
& 2-cylinder 988cc \\
\hline
\end{tabular}




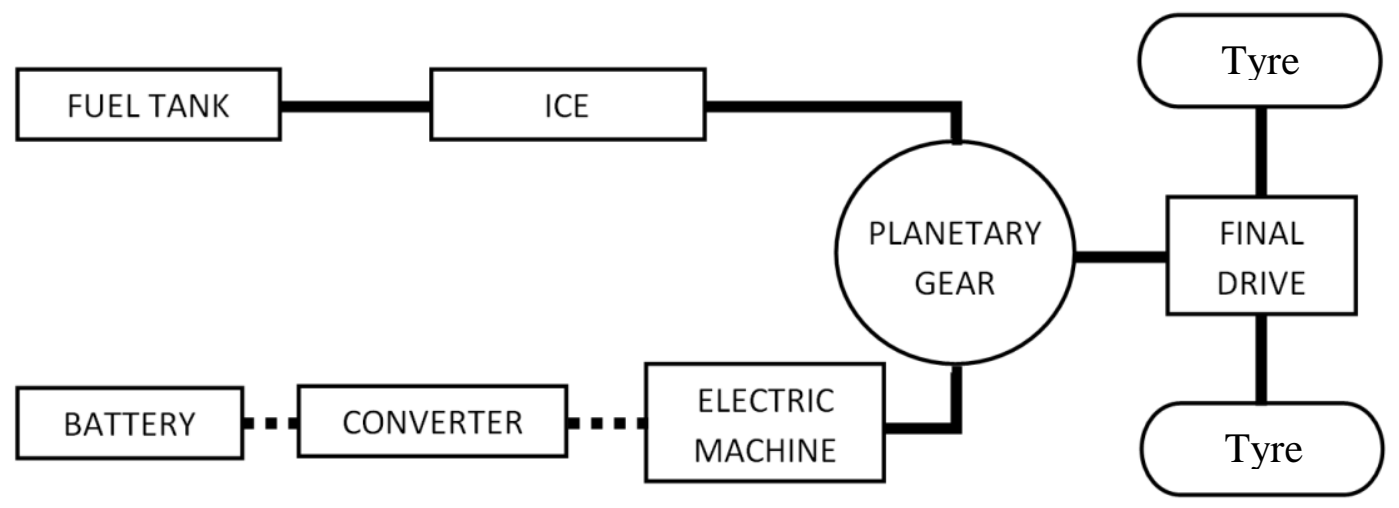

Figure 1. Parallel configuration of hybrid electric vehicle drive train.

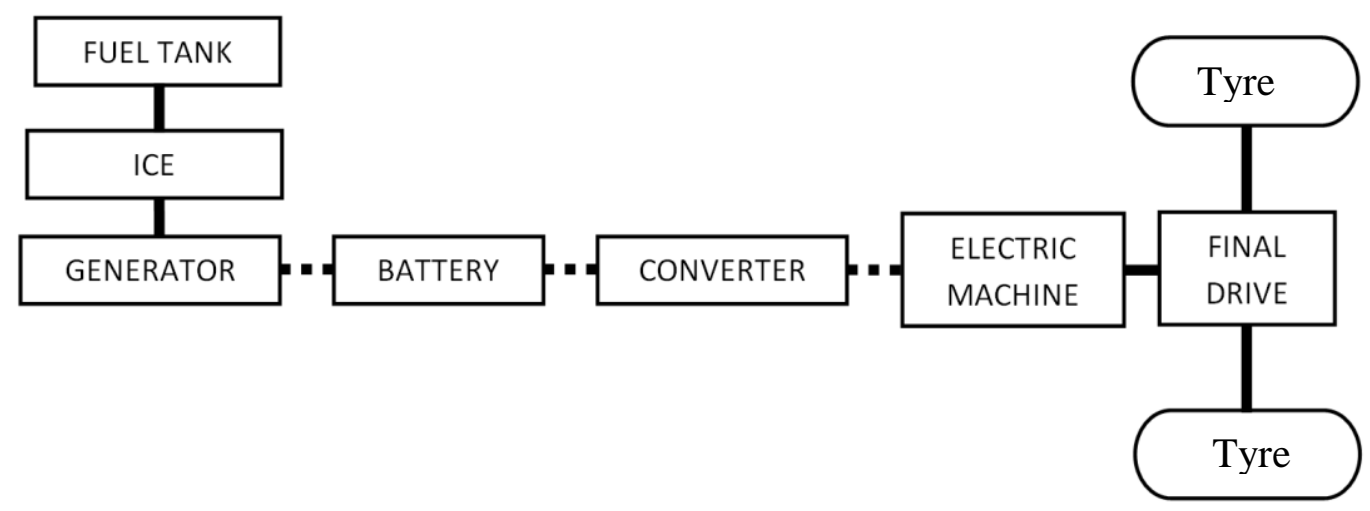

Figure 2. Range-extended electric vehicle (REEV) drive train configuration

\section{RANGE-EXTENDED ELECTRIC VEHICLE MODEL}

There is a graphical user interface (GUI) in AVL CRUISE that has the function of allowing the user to build the vehicle model or modify the basic AVL CRUISE model. Figure 3 is the model of the range-extended electric vehicle in series configuration, which has main components such as the internal combustion engine, generator, electric motor and battery. Each box in the model represents a component of the vehicle where the user can input data. Blue lines indicate the mechanical connection between components of the vehicle, red lines indicate electrical connections and black ones indicate the main components of the range-extended electric vehicle. In this simulation, the best performance of the range-extended electric vehicle can be achieved by simulating three kinds of internal combustion engine and piloting two driving cycles.

A driving cycle indicates a set point of vehicle speed versus time. It is used to measure the performance of the vehicle, fuel consumption and exhaust gas emissions. In the vehicle simulation, it can be used to compare the performance of vehicles, fuel consumption and exhaust gas emissions in many models. The driving cycle is performed on a chassis dynamometer, where emissions from the vehicle are collected and analysed to measure the emissions level. In this research, two kinds of driving cycle were used to test the performance of each vehicle model, i.e. the Artemis Rural Road cycle and FTP 75 cycle. The Artemis driving cycle was developed within the European Artemis (Assessment and Reliability of Transport Emission Models and Inventory Systems) project. It has three kinds of driving schedules: urban, rural road and motorway. In this research, the rural road cycle is used to simulate the vehicle model. 
This driving cycle mode is shown in Figure 4. FTP (Federal Test Procedure) 75 is a kind of driving cycle that is used to measure the emissions and fuel economy of passenger cars. This driving cycle consists of a cold start transient phase, stabilized phase and hot start transient phase. The hot start phase starts after the engine is stopped for 10 minutes (hot soak phase). This driving cycle mode is shown in Figure 5. Initially, the driving cycle was designed for fuel-based road vehicles, but it can now be used to predict the electric power consumption and driving range of hybrid electric vehicles.

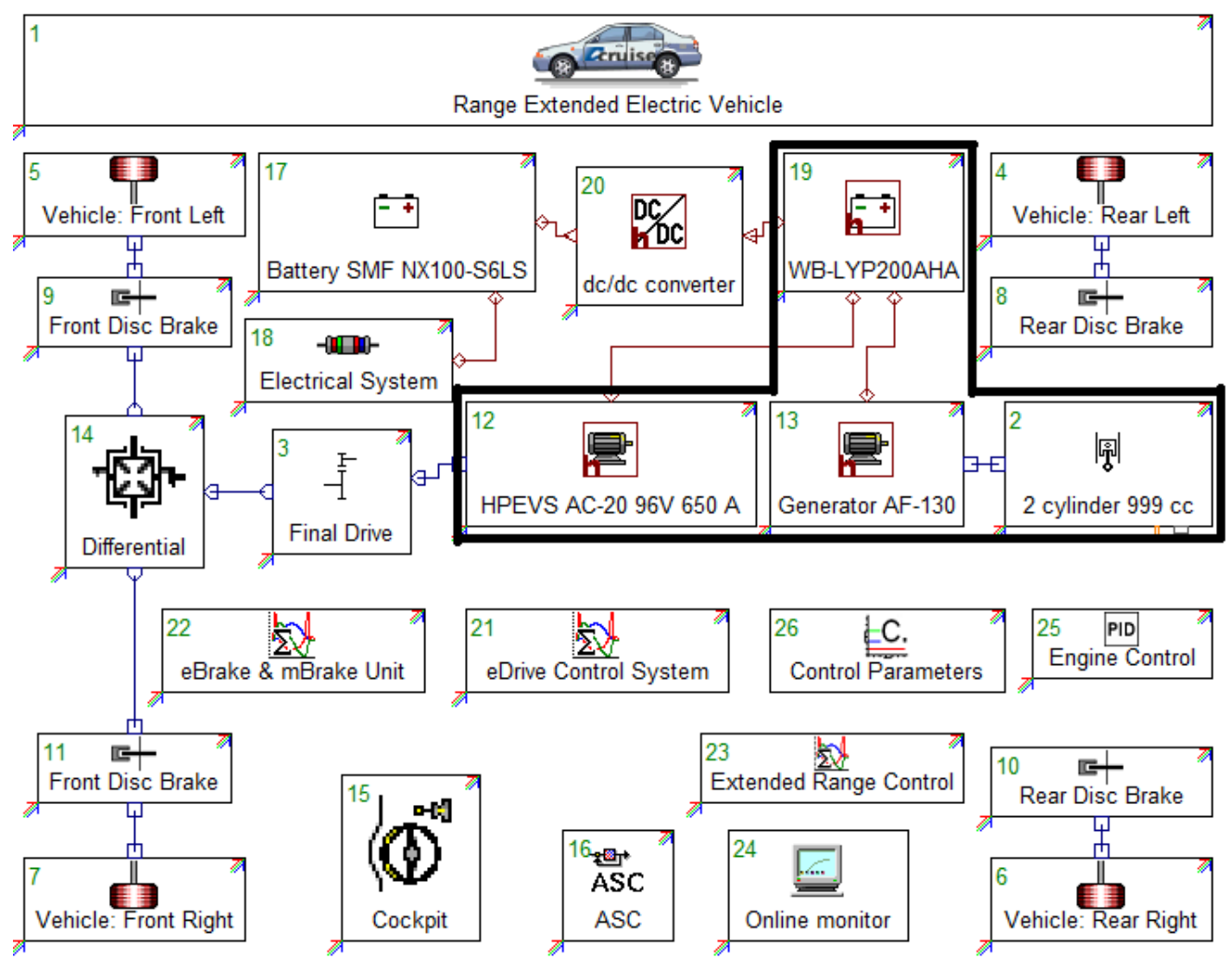

Figure 3. Range-extended electric vehicle model in AVL CRUISE.

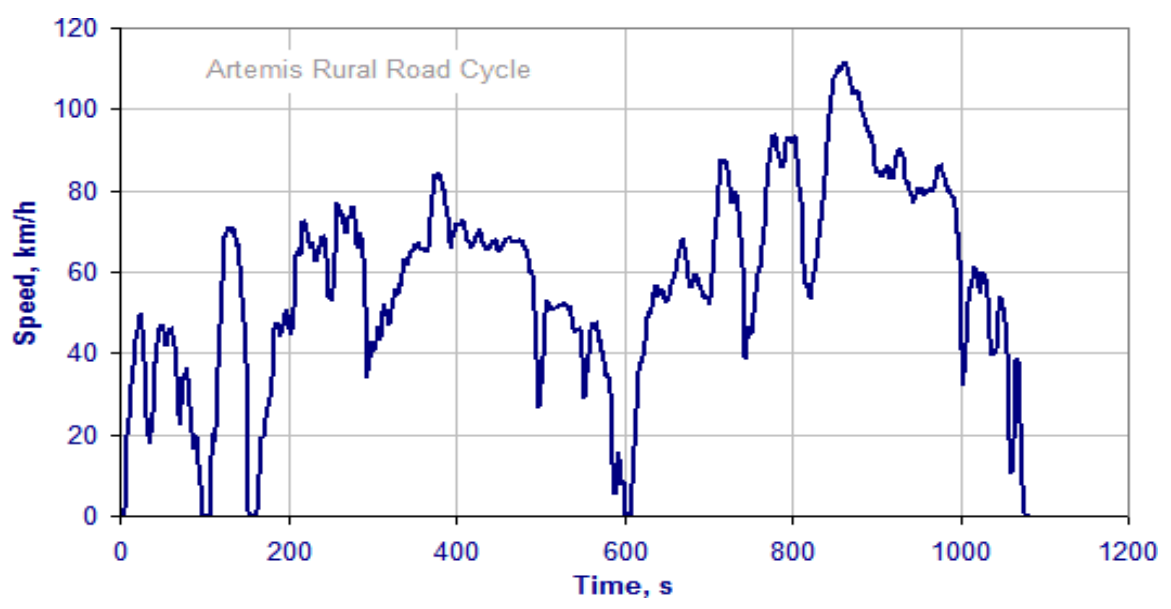

Figure 4. Artemis rural road driving cycle. 


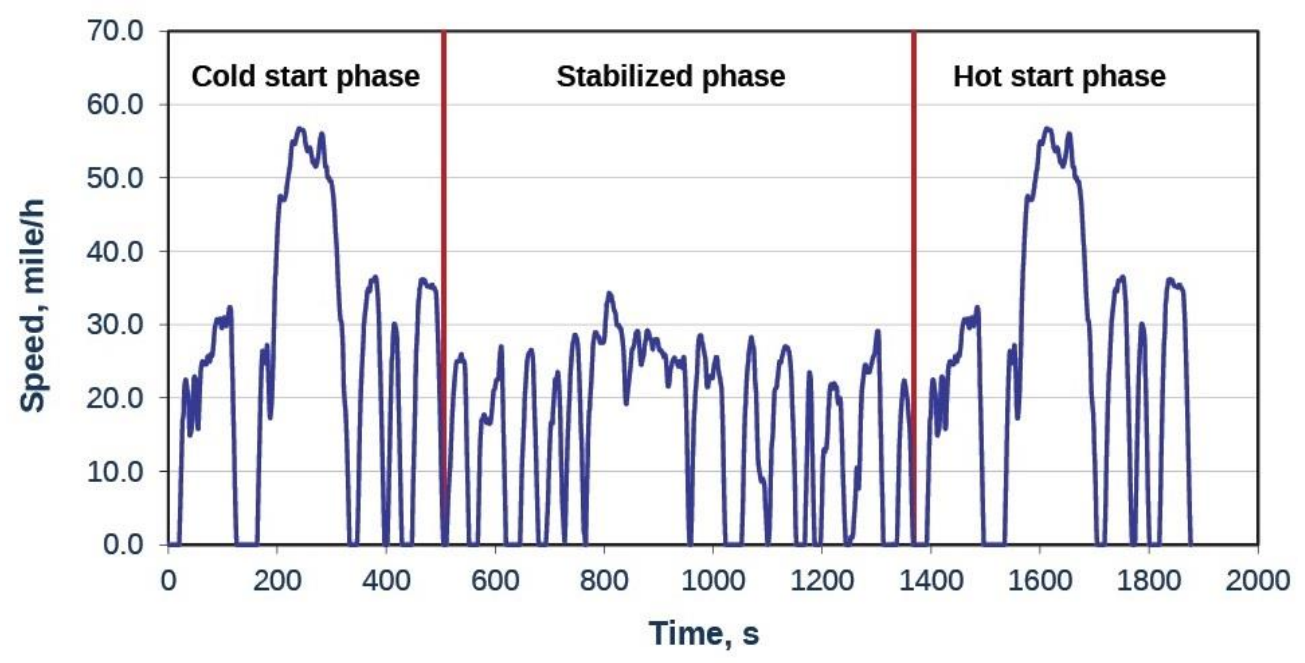

Figure 5. FTP 75 driving cycle.

\section{RANGE-EXTENDED ENGINE COMPONENT VARIATION}

In this model, three kinds of internal combustion engine are simulated to determine the performance of the best model of range-extended electric vehicle. Maps of the engine performance are collected by experiment at various speeds in the internal combustion engine laboratory and in simulation by AVL BOOST to get the maximum torque, BSFC (brake specific fuel consumption) maps and motoring torque at full or partial throttle in each engine. Table 2 shows the specifications of each internal combustion engine.

Table 2. Specifications of internal combustion engine.

\begin{tabular}{lccc}
\hline \multicolumn{1}{c}{ Engine Model } & 1 & 2 & 3 \\
\hline Engine type & Gasoline & Gasoline & Gasoline \\
Displacement & $389 \mathrm{cc}$ & $494 \mathrm{cc}$ & $988 \mathrm{cc}$ \\
Working & $80^{\circ} \mathrm{C}$ & $80^{\circ} \mathrm{C}$ & $80^{\circ} \mathrm{C}$ \\
temperature & 1 & 1 & 2 \\
Number of cylinders & 4 & 4 & 4 \\
Number of strokes & $5500 \mathrm{rpm}$ & $6000 \mathrm{rpm}$ & $6000 \mathrm{rpm}$ \\
Maximum speed & $1500 \mathrm{rpm}$ & $1500 \mathrm{rpm}$ & $1500 \mathrm{rpm}$ \\
Idle speed & $43500 \mathrm{~kJ} / \mathrm{kg}$ & $43500 \mathrm{~kJ} / \mathrm{kg}$ & $43500 \mathrm{~kJ} / \mathrm{kg}$ \\
Heating value & $0.737 \mathrm{~kg} / \mathrm{l}$ & $0.737 \mathrm{~kg} / \mathrm{l}$ & $0.737 \mathrm{~kg} / 1$ \\
Fuel density & $22.3 \mathrm{Nm} \mathrm{(2900}$ & $27.32 \mathrm{Nm} \mathrm{(3500}$ & $94.84 \mathrm{Nm}(3500$ \\
Torque maximum & $\mathrm{rpm})$ & $\mathrm{rpm})$ & $\mathrm{rpm})$ \\
\hline
\end{tabular}

The engine model as a range-extended engine can be inserted as a component within a vehicle model, and the fuel consumption can be estimated for all vehicle configurations and driving cycles. The full load torque output of each engine was input into CRUISE, as shown below in Figure 6. The motoring curve of each engine is shown in Figure 7. Utilizing the data points for each given engine speed, CRUISE was able to extrapolate. 


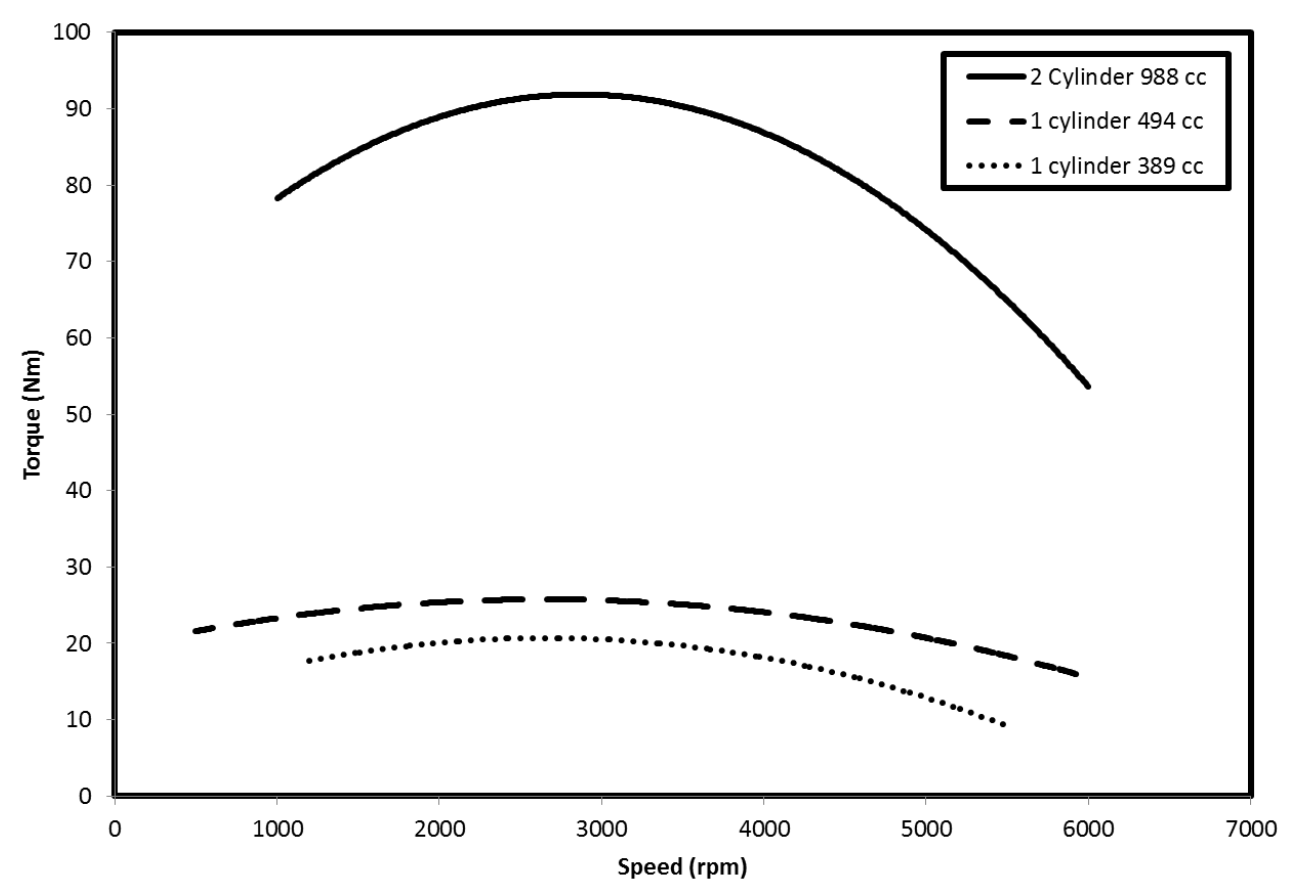

Figure 6. Full load torque output of internal combustion engine.

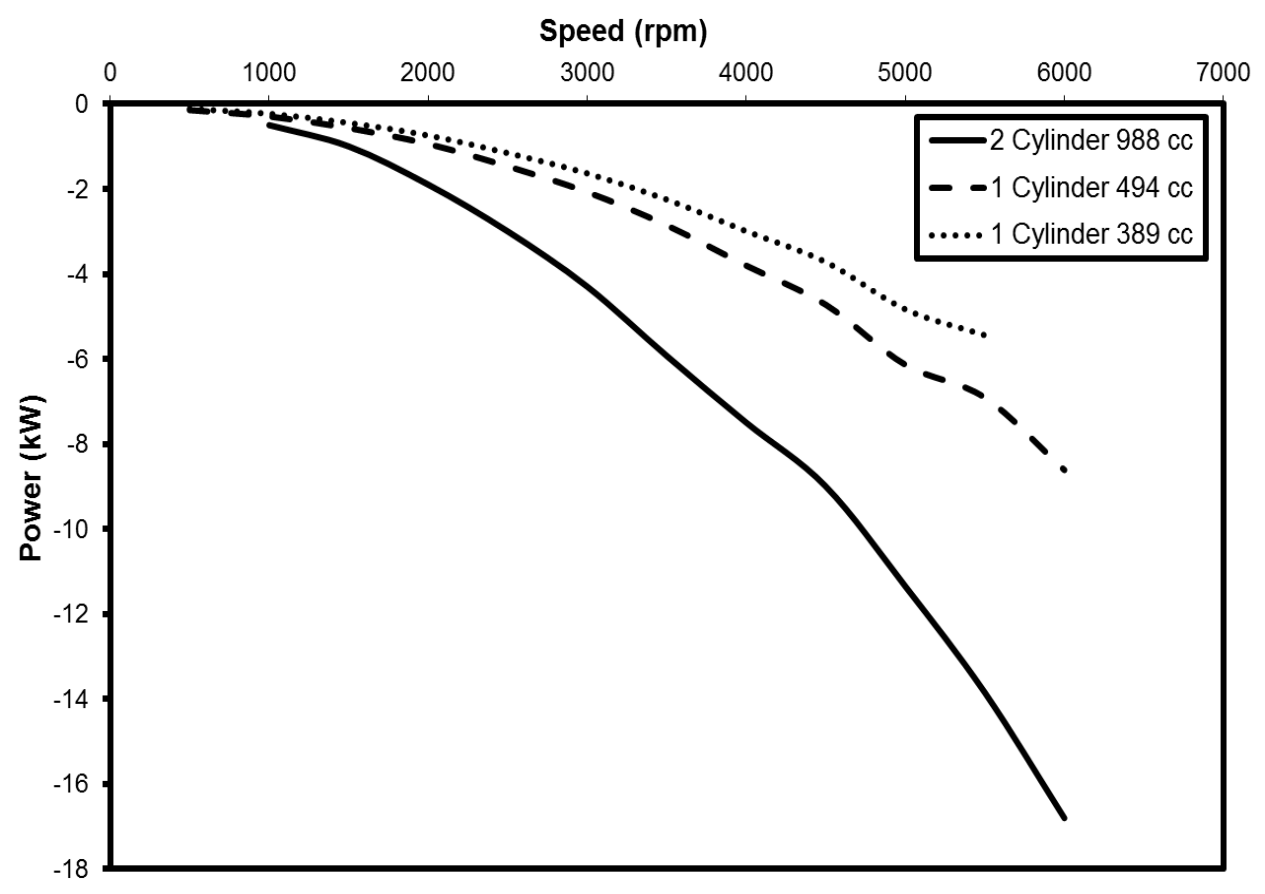

Figure 7. Motoring curve of internal combustion engine.

\section{RESULTS AND DISCUSSION}

The characteristics of the range extender can be shown by comparing the performance of an electric vehicle model without and with the range extender. Figure 8 shows an electric vehicle model without range extender that utilized an $\mathrm{AC}$ induction electric motor with a peak power output of $74.68 \mathrm{~kW}$ and $30 \mathrm{LiFeYPO}_{4}$ battery cells with a capacity of $200 \mathrm{Ah}$ as energy storage. In this research, the range extender system was 
applied in a range-extended electric vehicle with an engine speed of $3200 \mathrm{rpm}$. The range extender will be off as long as there is sufficient energy in the battery and will be activated whenever the SOC drops to $45 \%$. The range extender system remains active until the battery is charged to $50 \%$ SOC.

Table 3. Performance of vehicle configurations of various driving cycles.

\begin{tabular}{|c|c|c|c|c|c|}
\hline $\begin{array}{l}\text { Driving } \\
\text { cycle }\end{array}$ & Parameter & $\begin{array}{l}\text { Pure } \\
\text { EV }\end{array}$ & $\begin{array}{l}\text { RE with } \\
\text { 1-cylinder } \\
389 \text { cc }\end{array}$ & $\begin{array}{l}\text { RE with } \\
1- \\
\text { cylinder } \\
494 \mathrm{cc}\end{array}$ & $\begin{array}{l}\text { RE with } \\
\text { 2-cylinder } \\
988 \mathrm{cc}\end{array}$ \\
\hline \multirow{3}{*}{$\begin{array}{l}\text { Artemis } \\
\text { Rural Road }\end{array}$} & $\begin{array}{l}\text { Energy consumption of } \\
\text { electrical motor } \\
(\mathrm{kWh} / 100 \mathrm{~km})\end{array}$ & 18.91 & 18.18 & 12.72 & 3.77 \\
\hline & $\begin{array}{l}\text { Fuel consumption of } \\
\text { engine }(\mathrm{L} / 100 \mathrm{~km})\end{array}$ & - & 2.70 & 2.62 & 3.76 \\
\hline & Distance covered $(\mathrm{km})$ & 53.22 & 63.94 & 79.49 & 171.83 \\
\hline \multirow{3}{*}{ FTP75 } & $\begin{array}{l}\text { Energy consumption of } \\
\text { electrical motor } \\
(\mathrm{kWh} / 100 \mathrm{~km})\end{array}$ & 18.37 & 17.83 & 5.73 & 2.50 \\
\hline & $\begin{array}{l}\text { Fuel consumption of } \\
\text { engine }(\mathrm{L} / 100 \mathrm{~km})\end{array}$ & - & 4.45 & 6.21 & 4.06 \\
\hline & Distance covered $(\mathrm{km})$ & 51.01 & 58.50 & 118.23 & 174.82 \\
\hline
\end{tabular}
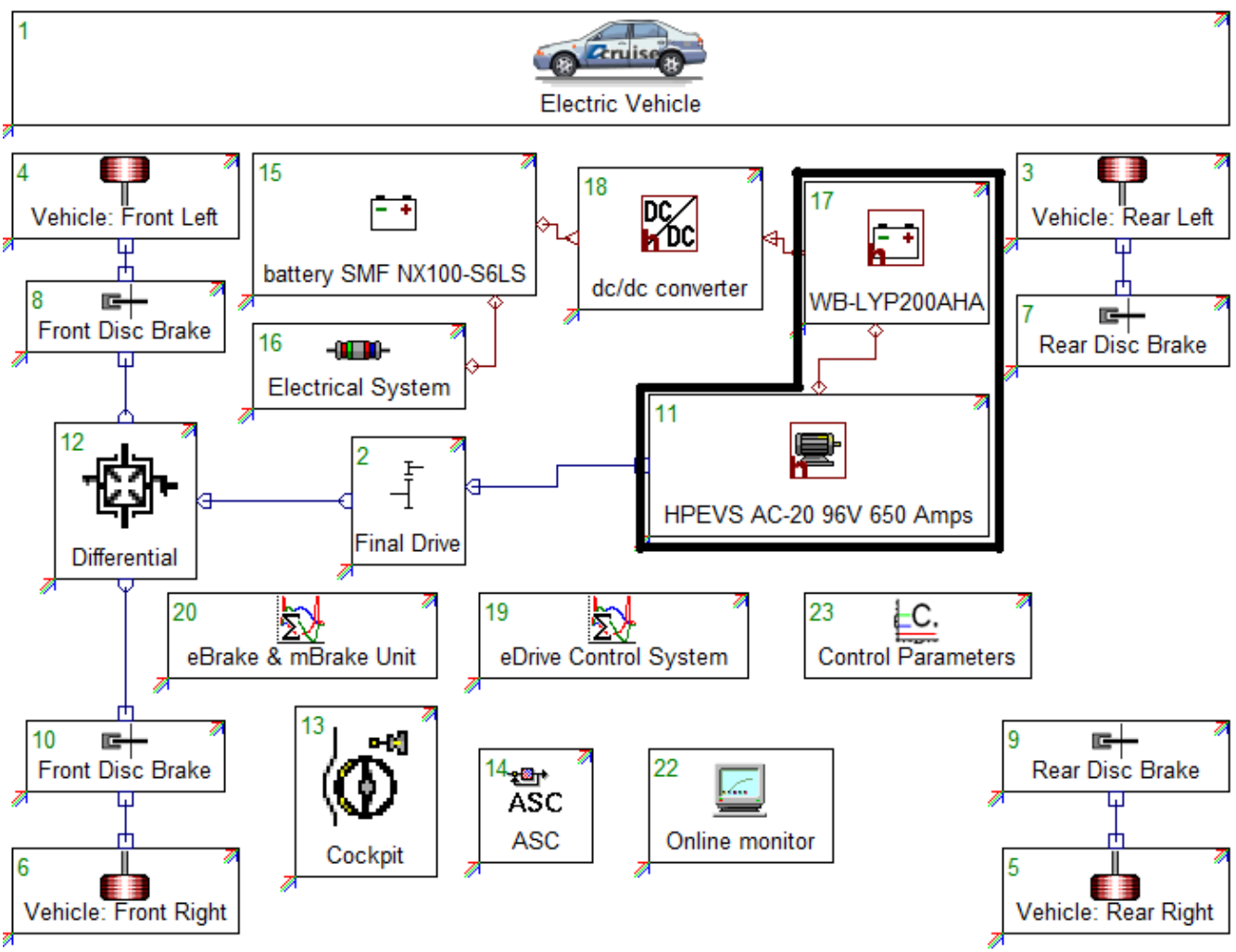

Figure 8. Electric vehicle model without range extender. 
The fuel consumption of the engine, energy consumption of the electrical motor and distance of each vehicle configuration over the two driving cycles are tabulated in Table 3. The range of the electric vehicle was evaluated as the distance covered while the batteries discharged from $90 \%$ to $30 \%$ SOC. This test was applicable to all vehicle configurations. Based on Table 3, the range-extended electric vehicle (REEV) model with 2-cylinder $988 \mathrm{cc}$ piloted for the Artemis Rural Road cycle and FTP75 cycle has the highest energy consumption of $3.135 \mathrm{kWh} / 100 \mathrm{~km}$ electrical motor. This is because the range extender for the 2-cylinder $988 \mathrm{cc}$ engine will only be activated when the battery has dropped to a value of $45 \%$ SOC and will stop after reaching $50 \%$ SOC. This happened repeatedly. This is in contrast with the REEV with the 1-cylinder $389 \mathrm{cc}$ engine and the REEV with the 1-cylinder $494 \mathrm{cc}$, which will be actived after the battery SOC drops to $45 \%$ and will remain active until the battery runs out of energy. In this condition, the supply of power provided by the engine is not able to make the battery SOC reach a value of $50 \%$ and is only able to withstand the SOC value so that it does not drop as significantly as the pure electric vehicle. This allows the range extender to provide insignificant additional mileage for electric vehicles. More detail can be seen in Figures 9 and 10.

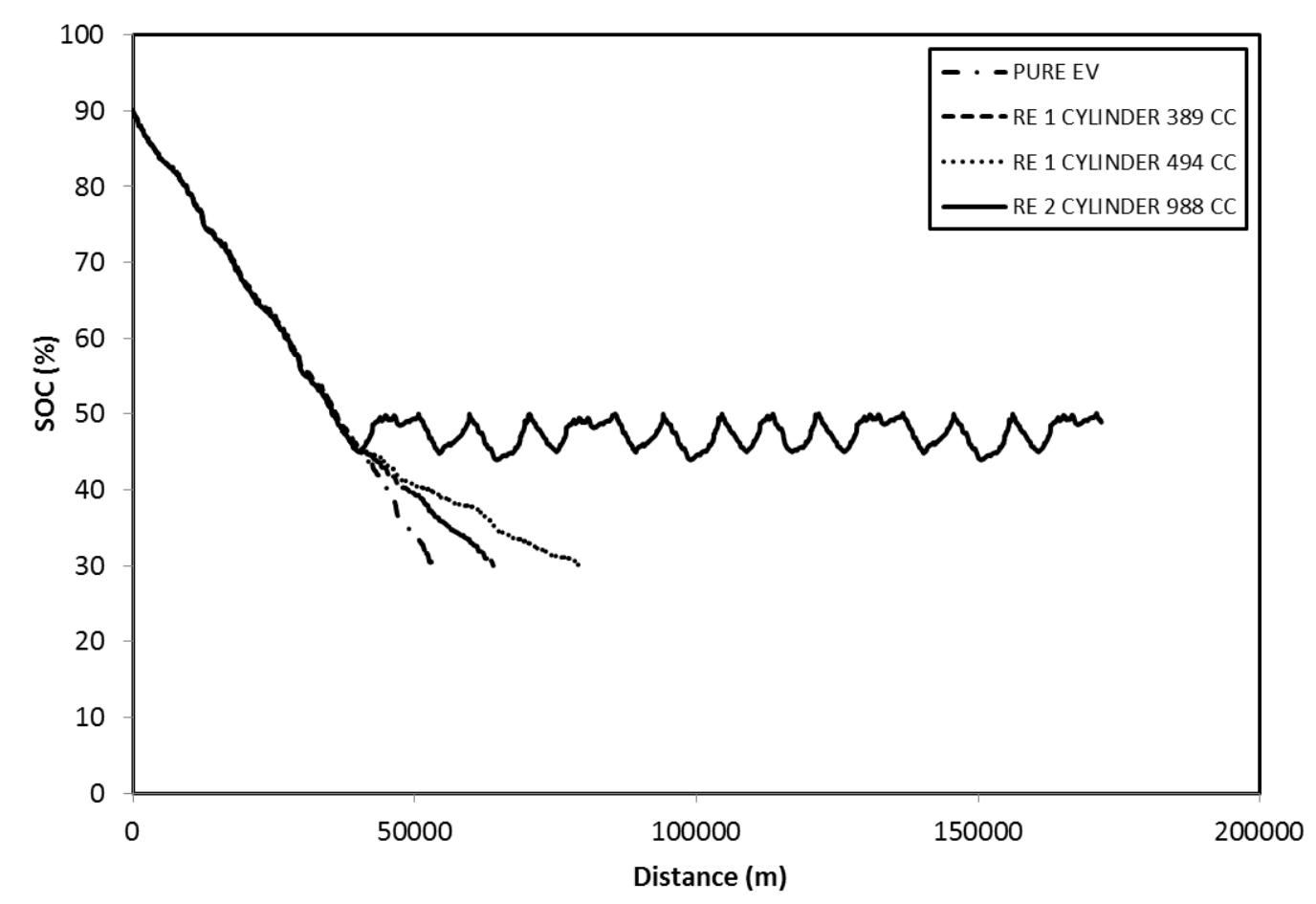

Figure 9. SOC of vehicle models simulated over Artemis Rural Road driving cycle.

The simulation was started by assuming several conditions; it was stated that the energy stored in the battery when the vehicle started to run was $90 \%$ of SOC as an initial charge and the vehicle would not run until the battery capacity was down to $30 \%$. The SOC point was set at $45 \%$ of battery capacity, which means that the electronic management system controlled the range-extended engine to turn on the gasoline engine and recharge the battery. The characteristics of the battery recharging operation for the range-extended engine are shown in Figure 9. 

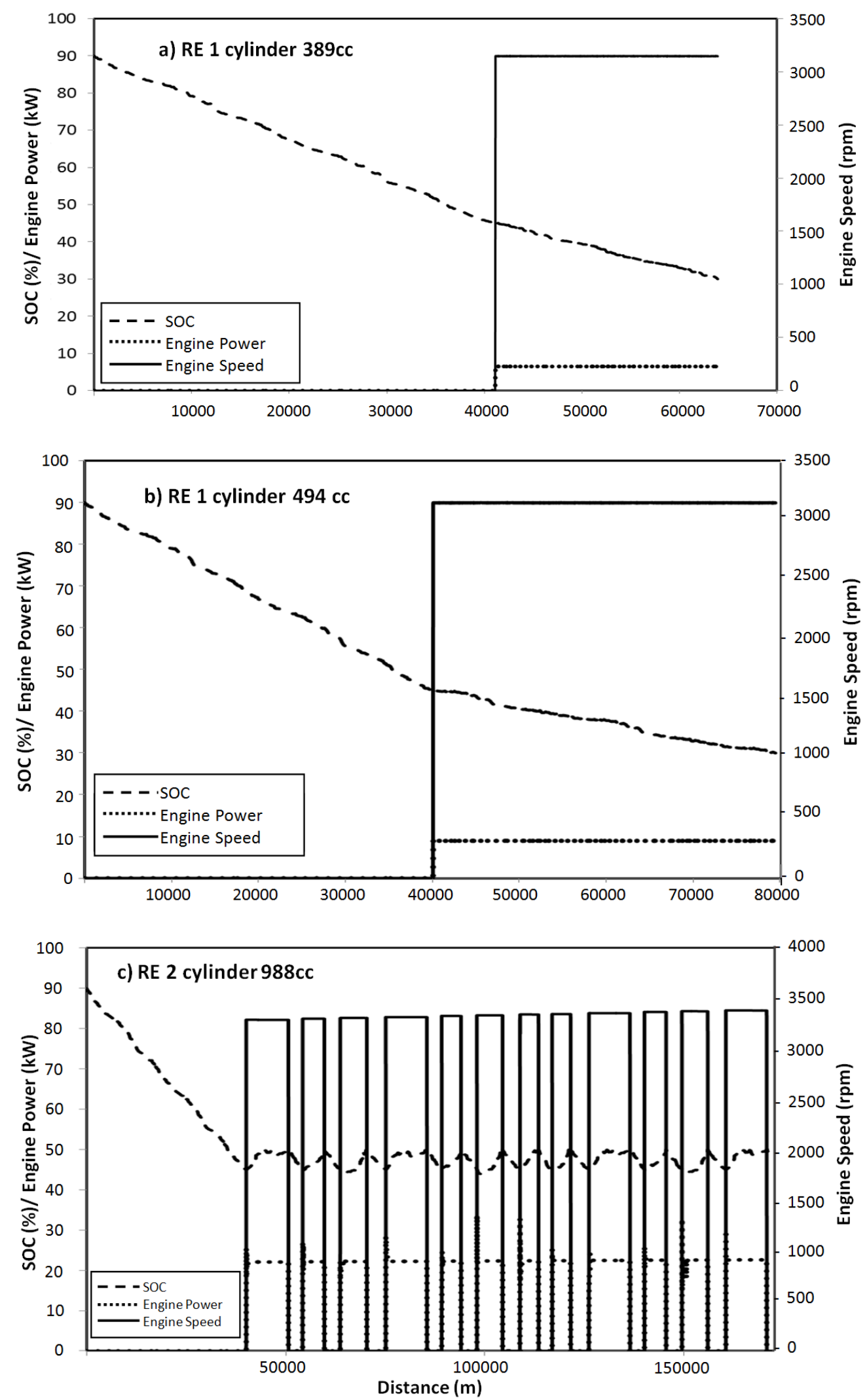

Figure 10. SOC, engine speed and engine power of REEV simulated over Artemis Rural Road driving cycle in: a) 1-cylinder 389 cc; b) 1-cylinder 494 cc; c) 2-cylinder 988 cc. 
On the pure electric vehicle, there is no battery recharging, so the curve is down significantly and stops when the energy from the battery reaches $30 \%$ capacity at only $53.22 \mathrm{~km}$ as the initial distance for the Artemis rural road cycle and up to $51.01 \mathrm{~km}$ as the initial distance when running on the FTP 75 cycle. For both of the single-cylinder range-extended engines which were installed in the electric vehicle, the road abilities of the vehicle slightly increase though the curve is still sloping downward, as can be seen on the slightly linear curve on the SOC point. All models show increasing road ability, but the first (electric vehicle with 389 cc gasoline engine) and second (electric vehicle with $494 \mathrm{cc}$ gasoline engine) models do not significantly increase the road ability of the REEV. The first and second models cannot maintain the condition of energy balance, so the energy recharge from the generator set is still lower than the energy consumed by the electric motor. For the third model (electric vehicle with 988 cc 2-cylinder gasoline engine), the range-extended engine maintains the condition of energy balance, so the range of the REEV becomes unlimited.

Figures 10(a)-(c) show the characteristics of the range-extended engine operation mode related to the battery SOC curve versus road ability (distance). Both Figures 10(a) and 10(b) have the same characteristics due to the poor electric energy generated by the generator set, and the range-extended engine cannot maintain the balance of the energy for that system. As a result, when the SOC curve is levelling off to its charge point, the generator set continues to work due to the poor energy generated. The range-extended engine's function of extending the mileage of the REEV is not working very well. Figure 10(c) shows the characteristics of the third system, the electric vehicle which is installed with the 2-cylinder $988 \mathrm{cc}$ gasoline generator set. The generator set is operated temporarily to charge the battery, and when the battery capacity is enough for the electric motor then the generator set will be shut off. When this characteristic occurs, it means that the road ability of the electric vehicle becomes unlimited, and is depending only on the conventional fuels used. This characteristic makes the generator set work as a range extender on the electric vehicle, the system known as REEV. Since the generator set works in its optimum zone, the advantages of the internal combustion engine as a range-extended engine and the advantages of the electric vehicle can be successfully achieved. Based on these results, using a range extender on an electric vehicle effectively improves the mileage of the vehicle. Based on this simulation, the third model (the electric vehicle with the $988 \mathrm{cc} 2$-cylinder engine) gives the best performance in terms of the energy consumption of the electrical motor, the specific fuel consumption for the range-extended engine and the distance coverage (road ability) of the REEV.

\section{CONCLUSIONS}

Based on the simulation results, the engine model using a two-cylinder $988 \mathrm{cc}$ engine has the best performance compared to the other models, can be applied as one component of a range extender, and can be implemented for the Indonesian Institute of Sciences (LIPI) electric vehicle. This range-extended engine model has the lowest fuel consumption of the electrical motor compared to the other models. Although the fuel consumption of the engine is similar, this engine is the most optimal model because it can cover greater distances than the other models. In the future, this range-extended engine model will be designed, prototyped and applied in the Indonesian Institute of Sciences (LIPI) electric vehicle. 


\section{ACKNOWLEDGEMENTS}

The author would like to thank the members of Internal Combustion Engine Laboratory, Research Centre for Electrical Power and Mechatronics, Indonesian Institute of Sciences for helping to get experiment data, especially Mulia Pratama and Ahmad Dimyani. The authors would like to thank Indonesian Institute of Sciences for providing financial assistance under Competitive Research Grant with project number 934/F/2014.

\section{REFERENCES}

[1] WHO. Global Health Observatory Data Reporting 2014. 2014.

[2] Harrington W, McConnell V. Motor Vehicles and the environment. resources for future; 2013.

[3] Chen B, Hong C, Kan H. Exposures and health outcomes from outdoor air pollutants in China. Toxicology. 2004;198:291-300.

[4] Fauzi A, Asdak C, Driejana, Hudyastuti S, Kusumo JP, Riqqi A, et al. Status Lingkungan Hidup Indonesia 2010. Kementrian Lingkungan Hidup Republik Indonesia; 2010.

[5] Sundvor I, López-Aparicio S. Impact of bioethanol fuel implementation in transport based on modelled acetaldehyde concentration in the urban environment. Science of The Total Environment. 2014;496:100-6.

[6] Dodić SN, Popov SD, Dodić JM, Ranković JA, Zavargo ZZ. Potential contribution of bioethanol fuel to the transport sector of Vojvodina. Renewable and Sustainable Energy Reviews. 2009;13:2197-200.

[7] Torres-Jimenez E, Pilar Dorado M, Kegl B. Experimental investigation on injection characteristics of bioethanol-diesel fuel and bioethanol-biodiesel blends. Fuel. 2011;90:1968-79.

[8] Balat M, Balat H. Recent trends in global production and utilization of bioethanol fuel. Applied Energy. 2009;86:2273-82.

[9] Park SH, Yoon SH, Lee CS. Bioethanol and gasoline premixing effect on combustion and emission characteristics in biodiesel dual-fuel combustion engine. Applied Energy. 2014;135:286-98.

[10] Tutak W. Bioethanol E85 as a fuel for dual fuel diesel engine. Energy Conversion and Management. 2014;86:39-48.

[11] Suryaningsih R, Irhas. Bioenergy plants in Indonesia: Sorghum for producing bioethanol as an alternative energy substitute of fossil fuels. Energy Procedia. 2014;47:211-6.

[12] How HG, Masjuki HH, Kalam MA, Teoh YH. Engine performance, emission and combustion characteristics of a common-rail diesel engine fuelled with bioethanol as a fuel additive in coconut oil biodiesel blends. Energy Procedia. 2014;61:1655-9.

[13] Badmaev SD, Snytnikov PV. Hydrogen production from dimethyl ether and bioethanol for fuel cell applications. International Journal of Hydrogen Energy. 2008;33:3026-30.

[14] Hasan MM, Rahman MM, Kadirgama K. A review on homogeneous charge compression ignition engine performance using biodiesel-diesel blend as a fuel. International Journal of Automotive and Mechanical Engineering. 2015;11:2199-211. 
[15] Azad AK, Rasul MG, Giannangelo B, Islam R. Comparative study of diesel engine performance and emission with soybean and waste oil biodiesel fuels. International Journal of Automotive and Mechanical Engineering. 2015;12:2866-81.

[16] Salleh I, Md. Zain MZ, Raja Hamzah RI. Evaluation of annoyance and suitability of a back-up warning sound for electric vehicles. International Journal of Automotive and Mechanical Engineering. 2013;8:1267-77.

[17] Rahmat MS, Ahmad F, Mat Yamin AK, Aparow VR, Tamaldin N. Modeling and torque tracking control of permanent magnet synchronous motor (PMSM) for hybrid electric vehicle. International Journal of Automotive and Mechanical Engineering. 2013;7:955-67.

[18] Zulkifli SA, Mohd S, Saad N, A. Aziz AR. Operation and control of splitparallel, through-the- road hybrid electric vehicle with in-wheel motors. International Journal of Automotive and Mechanical Engineering. 2015;11:2793-808.

[19] Salisa AR, Walker PD, Zhang N, Zhu JG. Comparative cost-based analysis of a novel plug-in hybrid electric vehicle with conventional and hybrid electric vehicles. International Journal of Automotive and Mechanical Engineering. 2015;11:2262-71.

[20] Seixas J, Simões S, Dias L, Kanudia A, Fortes P, Gargiulo M. Assessing the cost-effectiveness of electric vehicles in European countries using integrated modeling. Energy Policy. 2015;80:165-76.

[21] Salleh I, Zain Md. M.Z., R.I. RH. Evaluation of annoyance and suitability of a back-up warning sound for electric vehicles. International Journal of Automotive and Mechanical Engineering (IJAME). 2013;8:1267-77.

[22] Rahmat MS, Fauzi Ahmad, Ahmad Kamal Mat Yamin, and VRA, Tamaldin N. Modeling and Torque tracking control of permanent magnet synchronous motor (PMSM) for hybrid electric vehicle. International Journal of Automotive and Mechanical Engineering (IJAME). 2013;7:955-67.

[23] Omar SMHS, Arshad NM, Yassin IM, Fakharuzi MHAM, Ward TA. Design and optimization of powertrain system for prototype fuel cell electric vehicle. Journal of Mechanical Engineering and Sciences. 2015;8:1401-13.

[24] Mohd TAT, Hassan MK, A. Aziz WMK. Mathematical modeling and simulation of an electric vehicle. Journal of Mechanical Engineering and Sciences. 2015;8:1312-21.

[25] Jenn A, Azevedo IL, Fischbeck P. How will we fund our roads? A case of decreasing revenue from electric vehicles. Transportation Research Part A: Policy and Practice. 2015;74:136-47.

[26] Tate E, Harpster M, Savagian P. The Electrification of the automobile: From conventional hybrid, to plug-in hybrids, to extended-range electric vehicles. SAE International Journal of Passenger Cars - Electronic and Electrical Systems. 2009;1:11.

[27] Ke S, Jing Z, Tong Z. Design and development of a pluggable PEMFC extended range electric vehicle. Mechanic Automation and Control Engineering (MACE), 2011 Second International Conference on2011. p. 1144-7.

[28] Same A, Stipe A, Grossman D, Park JW. A study on optimization of hybrid drive train using Advanced Vehicle Simulator (ADVISOR). Journal of Power Sources. 2010;195:6954-63. 
[29] Dong T, Zhao F, Li J, Jin Q, You Y. Design method and control optimization of an Extended Range Electric Vehicle. Vehicle Power and Propulsion Conference (VPPC), 2011 IEEE2011. p. 1-6.

[30] Bao-Hua W, Yong-ge L. AVL cruise-based modeling and simulation of EQ6110 hybrid electric public bus. Computer Application and System Modeling (ICCASM), 2010 International Conference on2010. p. V7-252-V7-5.

[31] Milano F. An open source power system analysis toolbox. power systems, IEEE Transactions on. 2005;20:1199-206.

[32] Guotao S, L. L. Using the CRUISE to evaluate the effect of driving cycles on heavy-duty fuel economy. AST User Meeting 20052005.

[33] AVL. AVL Cruise Version 2011 User Guide. AVL List GmbH, Graz; 2011.

[34] AF-130 Generator Evo electric. EVO Electric; 2015.

[35] WB-LYP200AHA Winston battery. Winston Battery; 2014.

[36] AC-20 Torque \& Horsepower, High performance electric vehicle systems. HPEVS; 2014. 